\title{
Nepal Earthquake: ODOAN Experience and Initiative
}

\author{
Dr Dashrath Kafle
}

Time flies over us but leaves its shadow behind - Nathaniel Hawthorne

The bright and sunny day of 25th April 2015 was all of the sudden converted into Warfield within seconds. It was almost mid-day when Nepal was hard hit by 7.6 Richter scale earthquake with the epicentre $140 \mathrm{~km}$ west of Kathmandu at Barpak, Gorkha. We were in a state of war without enemy witnessing the cruel face of Mother Nature at its worst. We, Nepalese were raised with the tales and fables of "Nabbe Saal Ko Bhukampa (earthquake of 1933 AD)" which had happened eighty-two years back. We have heard the stories of earthquakes and tsunamis of Japan, Chili, China, Pakistan, Indonesia, Haiti and other countries. But we had never realised what goes into lives of the people who were hit by those calamities until we faced it by ourselves. It is indeed the second life many of us got on that day who survived. Even I could be one of the 8686 people who lost their lives or one of the 16808 who were injured. According to the official report, the Gorkha earthquake caused 500,223 houses fully destroyed and 269,156 partly destroyed. Likewise, 978 government offices were fully destroyed and 3021 were partly destroyed. A total of 4892 government schools were damaged, and in health sector; 26 hospitals were damaged and one private dental clinic building demolished. Nepal's 15 out of 75 districts are badly affected, including the Kathmandu Valley.

Time moved on its pace leaving behind the shadows in which the survivors have to live, struggle for shelter and food. Regular strong aftershocks, lack of basic items and lost communication further added misery to Nepalese people's life. Millions of Nepalese were sleeping on open ground under the shade of tarpaulin and tents fearing that earthquake will shake again. Still the important part is that; we are alive. For people who lost their family members, houses and cattle; the life will not be same again. It will take many years to heal the scar.

Whole nation was mourning. Despite limited resources Government was struggling to find the missing lives in grabbles, feeding hungry civilians and trying to reach millions of unreached. The job was not all that easy. The strong hands of Nepalese Army, Police and Armed Police worked and kind hearts of civilian society and humanitarian agencies helped. Many neighbouring and foreign countries supported promptly in this needful moment. Amidst this scenario, ODOAN and its members came out of their comfort zone and tried to help people in need. ODOAN Executive Committee came forward voluntarily to establish 'Earthquake Relief Fund' and opened a bank account to collect donation money from the contributors.

Soon after the earthquake, we started to get calls, emails and messages on social media from our friends and orthodontic societies abroad. Nepal was in their prayers and they were deeply concerned about the sorrow of Nepalese people. Indian Orthodontic Society (IOS) and its President promptly backed our earthquake relief fund as a symbol of brotherhood to Nepalese people. Later there were significant amount of contribution from Thai Association of Orthodontist (ThAO), Taiwan Association of Orthodontist (TAO), Korean Association of Orthodontist (KAO), Japanese Orthodontic Society (JOS), Association Philippines Orthodontists (APO), Sri Lankan Orthodontic Society (SLOS), British Orthodontic Society (BOS) and friends from Malaysia, China and Bangladesh. We were very fortunate to have friends and well-wishers around the globe who not only prayed for us but also supported our people in need.

Under the initiative of ODOAN, relief materials consisting of food, clothes and medical supplies were distributed in different remote villages affected by earthquake. Many ODOAN members participated in immediate relief program in remote areas in association with Nepal Dental Association. ODOAN could only contribute in a smaller scale as compared to the need of the nation. But that was a good start which has to take a long journey before it could conclude in a logical end. The relief stage of help was now waiting for reconstruction stage. ODOAN Executive Committee decided to spend the donation money to reconstruct demolished infra-structure of school building of the remote village in the hope that ODOAN's contribution will be sustained. In this phase, ODOAN chose 5 schools which were completely wrecked by the earthquake. ODOAN is now in the mission of reconstructing those damaged schools. These schools are located in 4 earthquake hit districts, viz: Kavre, Nuwakot, Sindhupalchok and Dhading. School construction has already been started in Nuwakot and Dhading districts and in remaining two districts; the work will start very soon. ODOAN has a further plan to build a 'Smile Library' where children enjoy reading books in a peaceful and cheerful manner.

With the mission of school rebuilding, ODOAN appealed for help at different national and international forums. We ECMs presented the post-earthquake scenario of Nepal and activities of ODOAN during 10th World Orthodontic Congress of World Federation of Orthodontists in London in October 2015. British Orthodontic Society has appealed the world orthodontic community to help Nepal through its official website. ODOAN General Secretary appealed for help during Sri Lanka International Orthodontic Conference in Colombo in February 2016. We have received huge promises and vows to support our noble mission. We take this special editorial issue to thank our friends and societies from home and abroad who selflessly contributed to our mission. We hope to continue this movement in future with all of your support. 